Postprint version of article Tourism networks unravelled; a review of the literature on networks in tourism management studies by Egbert van der Zee \& Dominique Vanneste published in Tourism Management Perspective, 15 (July 2015), pp 46-56

\title{
Tourism networks unravelled; a review of the literature on networks in tourism management studies
}

\section{Egbert van der Zee \& Dominique Vanneste}

Department of Earth and Environmental Sciences, KU Leuven, Celestijnenlaan 200E bus 2409, 3001 Leuven, Belgium

\begin{abstract}
This paper presents an overview of the current state of research into tourism networks, by providing a systematic literature review and relational citation analysis of 98 scientific papers focusing on network collaboration in tourism destinations. The aim of this study is to get a better understanding why the promising theoretical claims of potential benefits of networked collaboration in tourist destinations are so little supported by empirical evidence. This paper shows there are two explanations for this lack of empirically proven benefits. First, progress is hampered by the lack of integration within the field of tourism network studies. The citation analysis identified the existence of different sub-fields of research. These sub-fields apply different approaches towards tourism networks, both from a theoretical and from a methodological perspective. There is little cross-fertilization between the sub-fields and integrative studies are still scarce. Second, while many studies show interesting and promising findings, the field would make more progress, if researchers would reflect more systematically on the relationship between network goals and projected outcomes, and on the most suitable methodology to test the effects of the desired network development in a comprehensive way. Since networks thrive on the perspectives of future benefits that accrue from network participation, there is a need for empirical proof of these network outcomes. Examples of best practices should be provided which visualize and explain the benefits of networks. Tangible, quantitative benefits have to be found in order to stimulate tourism entrepreneurs investing time and money in local tourism networks.
\end{abstract}


Postprint version of article Tourism networks unravelled; a review of the literature on networks in tourism management studies by Egbert van der Zee \& Dominique Vanneste published in Tourism Management Perspective, 15 (July 2015), pp 46-56

\section{Introduction}

Tourism is a complex phenomenon. It is a temporary interaction between guests and a hosting destination which is made up of an amalgam of stakeholders, partially or fully, and directly or indirectly involved in tourism. A great diversity of public, private and hybrid parties are involved in tourism providing services, infrastructure, information and primary and secondary tourist products vital for a successful tourism destination. Still, the tourist perceives, experiences and consumes the destination as an integrated entity (Buhalis, 2000; Haugland, Ness, Grønseth, \& Aarstad, 2011). To grasp the complexity of managing a tourist destination, the concept of tourism networks has seen a rise in popularity during the last decades.

An important issue in this debate is the persistence of a gap between the various stakeholders in tourism. This gap was already noticed in the mid-seventies, when Gunn (1977) raised awareness of a lack of public-private collaboration in tourism planning which she considered as an impediment for sustainable tourism development. Since then the relationship and collaboration between stakeholders gradually became an independent area for research in the field of tourism, with an acceleration in published studies since the turn of the century after some key publications on stakeholder collaboration (Jamal \& Getz, 1995; Bramwell \& Lane, 2000), and the role of public and private stakeholders in the organization of tourism destinations (Tremblay, 1998; Hall, 1999) were published. In these years, the network concept found its way into tourism management studies as it could provide a "new" and "positive" mode of coordination that needed to be distinguished from markets and hierarchies' (Provan \& Kenis, 2008, p 233).

Hall (2005, p 179) defines a network as 'an arrangement of inter-organization cooperation and collaboration'. In the literature several positive values are attributed to tourism networks. Networks are proposed to function as systems which can organise and integrate tourism destinations, cause benefits for participating tourism firms, enhance destination performance and quality and stimulate the provision of 'wholesome and memorable experiences' for tourists (Zach \& Racherla, 2011, p 98).

The network approach has proven useful in various fields, among others sociology, economic geography and political sciences, with important contributions in the academic debate and resulting in all kinds of policy measures following this debate. In other fields, however, the network concept is still in a more immature phase. Provan \& Kenis (2008, p 229) argue that in for example public administration 'despite much progress made by 
Postprint version of article Tourism networks unravelled; a review of the literature on networks in tourism management studies by Egbert van der Zee \& Dominique Vanneste published in Tourism Management Perspective, 15 (July 2015), pp 46-56

researchers studying networks over the past 15 years and more, there is still a considerable discrepancy between the acclamation and attention networks receive and the knowledge we have about the overall functioning of networks'.

In tourism, a growing body of work has been devoted to uncovering the potential of the network concept for tourism development and management (see e.g. Albrecht, 2013). The first studies suggest that the tourism industry needs a network approach, because this would help destinations to function in a changing, complex and competitive world (Gretzel \& Fesenmaier, 2003; Cawley, Marsat, \& Gillmor, 2007). Inspired by Porter (1990), it was claimed that tourism destinations 'have a greater chance to be competitive on a national and global basis when their businesses are competing and collaborating at the same time' (Novelli, Schmitz, \& Spencer, 2006 p 1142). Working together in a complex system of simultaneous competition and collaboration demands a well-managed network of public and private stakeholders (Vargo \& Lusch, 2004). It was also claimed that the network perspective has the potential to serve as a tool which fosters innovation, knowledge sharing, competitiveness and sustainable economic development for the involved stakeholders (Novelli et al., 2006; Pavlovich, 2003).

However, in sharp contrast with the universal optimistic claims about the value of a network approach for the development of tourism destinations, the scientific effort to provide evidence for these claims is still in its infancy. The literature is divergent and sometimes contradictory in its recommendations. Albrecht (2013) for example, argues in her review of tourism network studies in favour of a research agenda with more longitudinal, qualitative studies. On the other hand, Baggio, Scott and Cooper (2010), argue that there is a shortage of quantitative social network analysis. Del Chiappa and Presenza (2013, p 2) add a new perspective to this discussion by arguing that aside from this quantitative - qualitative divide, the field of studies can be divided into studies delving into the 'evolution of businesses, product development, packaging and opportunities for further development' and networks as a 'channel for managing public-private relationships and understanding the structures of tourism and destination governance'. The different positions on tourism networks seem to exist parallel to each other and are seldom evolving into an academic debate. These contrasting claims and lack of agreement in the field of tourism network studies suggests that there might be too little cross-fertilization between the different approaches. It also seems that in the wider field of tourism network studies the network is conceptualised in different ways. 
Postprint version of article Tourism networks unravelled; a review of the literature on networks in tourism management studies by Egbert van der Zee \& Dominique Vanneste published in Tourism Management Perspective, 15 (July 2015), pp 46-56

Summarizing, discussions on the conceptualisation of tourism networks (Presenza \& Cipollina, 2010) and the type of methodology that should be applied to study networks (Scott, Baggio, \& Cooper, 2008a; Albrecht, 2013) have not yet been settled. Some vital questions are left unanswered. Among these is the most important question whether or not a network approach to destination management really leads to competitive advantage for the destination and its related tourism firms.

The aim of this paper is to review the literature on tourism networks from the various theoretical approaches available. Supported by a bibliometric citation network analysis, clusters of studies will be distinguished that use the same theoretical and/or methodological approach to tourism network studies. This so-called modularity analysis will also reveal how generated knowledge is disseminated within the scientific community. Taken together, these analyses aim to get a better understanding why the promising theoretical claims of potential benefits of networking in the tourist industry are so little supported by empirical evidence. The paper will be concluded with some recommendations for further research as well as practice implications.

\section{Theoretical basis: The claimed benefits of tourism networks}

The origin for the growing popularity of studies into tourism networks stems from a number of reasons. First, and perhaps most important, there has been an outcry for an alternative to public sector management of destinations due to the rise of a more managerial perspective on governance (Wray, 2009; Hall, 1999). A system of self-management by (private) local stakeholders was argued to replace public sector management (Tremblay, 1998). The role of the government should be restricted to the coordination of economic and social agents (Melián-González \& García-Falcón, 2003) and an active role as network brokers is suggested (Lemmetyinen \& Go, 2009; Vanneste \& Ryckaert, 2011). Competitive advantage is thought to originate from a successful alignment of the intra-destination relationships and interdependencies (Saxena, 2005; Zehrer \& Raich, 2010), while managing stakeholder relationships is considered in need of a network perspective on management.

Secondly, there is a general belief that participating in a collaborative tourism network produces benefits for tourism firms (Novelli et al., 2006; Morrison, Lynch, \& Johns, 2004). Through increased interorganizational learning and knowledge sharing, social capital is acquired. This is believed to increase the competitive position of tourism firms (Halme, 2001; Sørensen, 2007), because collaboration reduces transaction costs for network firms (Erkuş- 
Postprint version of article Tourism networks unravelled; a review of the literature on networks in tourism management studies by Egbert van der Zee \& Dominique Vanneste published in Tourism Management Perspective, 15 (July 2015), pp 46-56

Öztürk, 2009) and creates added value and enhances the tourist experience (Fuglsang \& Eide, 2013) in destinations with a high level of networked collaboration among its tourism firms.

Thirdly, in order to reap the benefits of networked collaboration, perceiving the intradestination organization as a network helps to grasp the complex nature of stakeholder relationships. The supply structure of the tourism destination is characterized by a wide variety of complementary and competing stakeholders who are interrelated and, together, shape the tourism product (Ramayah, Lee, \& In, 2011; McCabe, Sharples, \& Foster, 2012; Adiyia, Stoffelen, Jennes, Vanneste, \& Ahebwa, 2015). These organizations have a relationship of dependency because 'suppliers pass customers from one organization to another in order to provide a comprehensive tourism experience' (Pavlovich, 2003, p 203). Hall (2005) points out that a network may turn into a physical "consumption route" sending tourists from one firm location to the other and in so doing creating an integrated tourism product offering. Considering that a tourist destination is perceived as a holistic product by tourists (Haugland et al., 2011), the integration of a tourist destination is important as tourists expect a smoothly organized value chain in which the different elements of the tourism experience are coordinated and aligned to suit the needs of the tourist (Van der Zee \& Go, 2013). Wäsche, Dickson and Woll (2013) argument that destination management for this reason cannot focus on single entities within a destination, but should adopt a network perspective to include a wider selection of stakeholders and their interdependencies in a destination. 'The success of a destination thus depends on the seamless coordination of the players comprising the tourism value chain' (Zach \& Racherla, 2011, p.98). In sum, it is the overall inter-firm network configuration that leads to competitive advantage (Denicolai, Cioccarelli, \& Zucchella, 2010; Hall, 2005).

Fourth, the increasing complex nature of tourism calls for a management system which is able to respond to change and volatility to function in a continuously changing environment (Dwyer, Edwards, Mistilis, Roman, \& Scott, 2009). Tourism is extremely sensitive to change of context beyond the sphere of influence of local tourism actors. The demand for a destination is influenced by a large set of variables ranging from changing tourists' tastes to the entry of new and alternative destinations competing for the same clientele. Political disturbances or natural disasters can negatively alter the attractiveness of destinations (Miller \& Ritchie, 2003) while positive reviews by travel media can put destinations on the mental maps of potential visitors (Buhalis, 2000). A tourism destination is thus highly dependent on the wider, unpredictable and unmanageable context. Being flexible, 
Postprint version of article Tourism networks unravelled; a review of the literature on networks in tourism management studies by Egbert van der Zee \& Dominique Vanneste published in Tourism Management Perspective, 15 (July 2015), pp 46-56

resilient and able to adapt to change seems to be the only way out of potential destination decline. Destinations characterized by network collaboration are argued to be more able to cope with these external influences. Not only can networks provide economies of scale for small and medium enterprises, also networked collaboration is argued to increase resilience of the stakeholders involved (Luthe, Wyss \& Schuckert, 2012) and innovative products and policies are more likely to be developed by a networked collaboration of stakeholders (McCabe et al., 2012).

From this theoretical exploration it may be concluded that - in principle - the tourism industry might benefit from a network approach. Now it is time to explore to what extent the published literature lives up to these expectations.

\section{Study design}

In this study, a relational bibliometric analysis is conducted to uncover the structure of the research field of tourism network studies. Citation network analysis is a methodology which is applied to uncover patterns of knowledge dissemination which are not visible at first glance, and to provide an overview of an academic discipline from a relational perspective that goes beyond citation rankings. 'Relational techniques explore relationships within research, such as the structure of research fields, the emergence of new research themes and methods' (Benckendorff \& Zehrer, 2013, p.126). The methodology of this study is partly based on the pioneering work by Benckendorff and Zehrer (2013), who are among the first to apply citation network analysis in a tourism context. The approach applied in this paper differs in three important ways from the approach by Benckendorff and Zehrer (2013). Firstly, this study aims to give an insight into the current position of the subfield of tourism network studies by including all available scientific papers published in this subfield of tourism research on network collaboration, while Benckendorff and Zehrer (2013) focus on a selection of the most important journals and highlight the most important authors and publications in the field of academic tourism research. Secondly, the review in this paper applies a modularity analysis to uncover clusters within the field of tourism network research. The modularity analysis shows whether we can distinguish clusters by looking at the citing behaviour of the included papers. Since citing shows a relation of knowledge sharing, the structure of the field based on citing behaviour and its subdivision into clusters can provide important insights into the development of the field of tourism network studies. Thirdly, a 
Postprint version of article Tourism networks unravelled; a review of the literature on networks in tourism management studies by Egbert van der Zee \& Dominique Vanneste published in Tourism Management Perspective, 15 (July 2015), pp 46-56

meta-analysis is presented on the distinguished conceptualization of the various types of tourism networks with a focus on (the gap between) assumed and empirically proven outcomes of the different studies.

To fully grasp the current position of the field of tourism network research, a systematic literature review has been conducted. It is systematic in the sense that a comprehensive overview is given of academic papers published in internationally peer reviewed journals from the year 2000 till February 2014. The year 2000 was chosen because even though the network concept was introduced in tourism studies before the year 2000, papers going explicitly into tourism networks started to appear after the turn of the millennium. A systematic literature search was undertaken in two steps. First, Google Scholar was used with the query "tourism network". From the first 400 hits, the paper abstracts were analyzed and papers were selected that address network collaboration in a tourism context. Papers addressing other types of networks, for example transport, ICT or neural networks were not selected. The reference lists of the selected papers were cross checked for additional literature. In total, 48 papers were found using this search query.

In order to triangulate the results, a second search query was applied using the Scopus database. The search query looked for internationally peer reviewed journal papers which contained (all variations of) the words tourism and network, in the title, keywords or abstract. This led to a total of 932 search hits. All papers have been reviewed by the authors based on the criteria that their main aim and scope should be the study of network collaboration in a tourism context. The selection process left a total of 98 papers which have been included in the citation analysis.

From the 98 papers included in the citation network, 8 papers did not refer to any of the other included papers, nor have they been referred to by papers included in the citation network. The impact of these 8 papers on the scientific development of the field is thus negligible. The remaining 90 papers are more or less structured in distinct citation patterns. Where most relational bibliometric studies conduct co-authorship analysis to show the most important authors in a field (Benckendorff \& Zehrer, 2013), we opt for a relational citation analysis to uncover the structure of the field of tourism network studies in general. Two types of analysis have been performed on the selected papers: (a) a citation analysis which shows the bibliometric relationship between the papers, and (b) a modularity analysis which shows the presence of clusters within the network of papers. 
Postprint version of article Tourism networks unravelled; a review of the literature on networks in tourism management studies by Egbert van der Zee \& Dominique Vanneste published in Tourism Management Perspective, 15 (July 2015), pp 46-56

To perform a citation analysis, the authors manually produced a citation matrix that shows for every of the selected papers to which other papers it refers and shows the papers by which it is referred to. The citation matrix was analysed and visualised using UCINET network analysis software (Borgatti, Everett, \& Freeman 2002). The nodes in the network are papers, coded by the year of publication and a following alphabetical letter code to indicate the order of publication in the given year. Node 02A is for example the first paper published in 2002 (see figure 1). The links between the nodes show the citation relationships within the network. The citation matrix allows to visualise the direction of the citing relationship which is visualised by an arrow connecting the citing paper to the cited paper. Distinguishing the direction is important because it shows which papers have a high centrality measure because they are cited often by other papers (high in-degree, influential papers), and which papers have a high centrality because they cite many other papers (high out-degree, disseminating papers). The position within the visualised network (figure 1) shows the centrality based on geodesic distance to other nodes, a central position within the network is determined by a high number of citing relations.

The second part of the analysis delves into the structure of the network. The visual representation of the network hints the presence of various clusters of nodes. To determine whether these clusters are present and which papers exactly belong to which clusters, a modularity analysis has been conducted. The modularity measure is used to distinguish clusters within the citation network. It was calculated using an algorithm created with the software package " $\mathrm{R}$ " and its programming language and environment (R Core Team, 2013). The modularity measure is an outcome based calculation of clusters in a network, given the density of linkages between nodes which are in this case citations. The modularity within the network shows the fraction of the nodes that fall within a given group compared to the number of nodes that would fall within the group when they would be randomly distributed. In other words, the modularity analysis shows whether there are clusters present within the citation network. We found seven clusters and a modularity score of 36 percent which shows that the number of papers that fall within the distinguished clusters exceeds the expected number of papers when it would be randomly distributed sginificantly. The found cluster distribution was imported and visualised (see figure 1) using the NetDraw application of UCINET (Borgatti et al., 2002). The clusters of papers were analysed on recurring themes, perceived and proven network benefits, conceptualisation of networks and applied methodologies. 
Postprint version of article Tourism networks unravelled; a review of the literature on networks in tourism management studies by Egbert van der Zee \& Dominique Vanneste published in Tourism Management Perspective, 15 (July 2015), pp 46-56

\section{Results}

\section{1 The 'founders' of network studies in tourism}

Although some incidental papers on collaboration between stakeholders in a tourism destination were published before (see e.g. Gunn, 1977), the real boost in collaborative network studies in tourism starts in the late '90s with the works of Jamal \& Getz (1995) on stakeholder collaboration, Tremblay (1998) on the economic organization of tourism, and Hall (1999) on public-private governance relationships. These important milestone papers all reflected on the applicability of a network perspective on tourism. Comparing these first contributions, we found that the current field of tourism networks is based on pillars departing from a different perspectives on the tourism network. An often cited paper by Jamal \& Getz (1995) for example, states that in order to cope with a changing and increasingly complex context in which tourism destinations need to perform, a higher level of collaboration is necessary. Collaboration between tourism stakeholders, planners and policy makers is in this case the prime focus. Studies into policy networks (see e.g. Tyler \& Dinan, 2001), community tourism networks (Kokkranikal \& Morrison, 2011) and public-private network organization (see e.g. Lemmetyinen \& Go, 2009) build on this proposed network perspective by Jamal \& Getz (1995) to study stakeholder relationships and apply the work by Bramwell \& Lane (2000) to study stakeholder collaboration.

A second influential paper on networks by Tremblay (1998) addresses the economic organization of tourism. A network perspective is suggested to overcome outdated mainstream economic theory in order to explain the organization of the supply side in tourism. A network economy originating from inter-firm cooperation is suggested as a potential structure to organize tourism. A typology of tourism networks is proposed with a strong emphasis on horizontally organized business networks, and limited involvement from public stakeholders. Studies into firm performance (see e.g. Sundbo, Orfila-Sintes, \& Sørensen, 2007), network configuration (Scott, Cooper, \& Baggio, 2008b) and inter-firm cooperation (Lemmetyinen, 2009) build on this perspective on tourism networks.

A third track of literature raises questions on the direct applicability of the network concept to the field of tourism as it is applied in the work of Tremblay (1998). Hall and Page $(2009, \mathrm{p} 7)$ raise caution concerning the direct translation of 'narrow economic or business approaches' to the complex tourism sector. Hall (1999) stresses the importance of public 
Postprint version of article Tourism networks unravelled; a review of the literature on networks in tourism management studies by Egbert van der Zee \& Dominique Vanneste published in Tourism Management Perspective, 15 (July 2015), pp 46-56

parties in tourism planning and policy making, and states that 'policy arguments surrounding networks and collaboration need to be examined within broader ideas of "governance" (Hall, $1999 \mathrm{p} 286$ ). In later contributions, this viewpoint is followed and translated into network studies as governance is described as a networked alternative for traditional public sector government (Cooper, Scott \& Baggio, 2009). A body of literature into tourism policy networks (see e.g. Dredge, 2006a) and the role of brokers (see e.g. Vanneste \& Ryckaert, 2011) draws upon this perspective on tourism networks forming another pillar in the current field of tourism network research.

Although the current field of tourism network studies branched out from these three initial publications, the base of tourism network studies is heavily influenced by other fields of studies as well. Network theory and (social) network analysis originate from the field of mathematics and have been influential in fields like economic geography (see e.g. Boschma \& Frenken, 2006), sociology (see e.g. Granovetter, 1973) and political sciences (see e.g. Knoke, 1990). Concepts and approaches in tourism network studies have thus been borrowed from other fields of application, with the work by Granovetter (1973) on the distinction between strong and weak network ties and the work by Uzzi (1997) on the effects of network embeddedness as prime examples. The rich recent history of network theory in other scientific fields fuels the estimation that the application of network theory on the field of tourism research could provide valuable new contributions for tourism studies.

It may be concluded that the rise in network studies has many fathers. The next section will look into the development of the tourism network literature by analyzing a systematic selection of tourism network papers and determining the current state of this field of research by unravelling the citation network of these papers. Secondly, it lists the main contributions from these studies for tourism management.

\subsection{Current state of the art}

The structure of tourism network studies has been described before. In their seminal book into network analysis in tourism, Scott et al. (2008a) divide the field based upon the methodology applied to study tourism networks. They argue there is a mainly quantitative approach originating from the mathematical origins of network studies and a mainly qualitative approach applying various in-depth enquiries into network relations and stakeholder perceptions. This subdivision is subsequently applied by Albrecht (2013) who claims an overrepresentation of quantitative network studies is currently present. A second 
Postprint version of article Tourism networks unravelled; a review of the literature on networks in tourism management studies by Egbert van der Zee \& Dominique Vanneste published in Tourism Management Perspective, 15 (July 2015), pp 46-56

subdivision is proposed by Presenza and Cipollina (2010) and Del Chiappa and Presenza (2013) who make a distinction between network studies going mainly into public-private relations and tourism policy versus studies focusing on tourism firm performance and inter firm relations. The work on the former "policy networks" builds upon the foundation proposed by Hall (1999) while the work on the latter "business networks" draws upon the propositions by Tremblay (1998).

Studies into policy networks and business networks are characterized by different theoretical approaches, research questions and methodology. When analyzing the papers reviewed in this study, both distinctions based upon methodology and the division between "business" and "policy" network studies seem to be too restrictive and generalizing to grasp the more complex reality of the current state of tourism network research. Studies combining qualitative and quantitative methodologies are fairly common in this field, and an important share of the studies is not easily placed in either the "business" or "policy" network subfield. However, clusters of papers adopting a different point of view towards tourism networks, drawing upon different theories and applying different methodologies can be distinguished. While all papers use tourism networks as their starting point, the choices made produce different outcomes and perspectives towards the contribution of the network perspective for tourism management.

\subsection{Systematic modularity analysis}

To uncover the structure of the field of network studies, and to find whether clusters are present, a modularity analysis has been conducted using the citation matrix of the included 90 connected papers as input (see figure 1). We can state positively that there are clusters, or subfields of scientific work, to be distinguished within the field of tourism network studies. The applied algorithm distinguished seven different clusters, of which four major, centrally located clusters and three minor, marginally located clusters. The two subfields suggested by Del Chiappa and Presenza (2013) are clearly distinguishable in this modularity analysis, with "policy networks" and "business networks" clusters located on the left and right side of the network graph (figure 1). The graph shows a gap between these two clusters which proves that papers into "policy networks" and "business networks" are not likely to cite each other. The correspondence of these clusters with the distinction proposed in the literature strengthens the validity of the analysis. Interestingly, however, the modularity 
Postprint version of article Tourism networks unravelled; a review of the literature on networks in tourism management studies by Egbert van der Zee \& Dominique Vanneste published in Tourism Management Perspective, 15 (July 2015), pp 46-56

analysis provides additional clusters of network studies which would have gone lost if no deeper analysis was conducted.

Next to the "business network" and "policy network" clusters, two more centrally located and influential clusters can be distinguished. Both clusters are positioned in a horizontal orientation with network nodes located among, and therefore related to, both policy network papers and business network papers (figure 1). Various papers from these clusters are located between the "policy network" and "business network" cluster, bridging the gap between them. These clusters contain papers that combine both main perspectives on tourism networks and, to a certain extent, integrate the traditional subfields. One of these clusters goes into tourism stakeholder relationships (Jamal \& Getz, 1995; Bramwell \& Lane, 2000) and the balance between competition and collaboration in a destination drawing upon Porter (1990). This cluster is labeled "network co-opetition" due to its focus on stakeholder relationships and the philosophy that competing and collaborating at the same time strengthens the destination and improves stakeholders performance. The other cluster goes back to the roots of network theory and draws upon a more mathematical network perspective (Scott et al., 2008a). Papers in this cluster go into the structure of the network and the nature of the network relations, and is therefore labeled "network configuration". Both clusters witness a strong increase in the number of contributions from 2008 onwards.

Finally, three smaller and marginally located clusters can be distinguished, which we labelled "other clusters". These clusters address one-issue networks like marketing and sports and event networks. Three papers forming a small cluster on the right side of the network graph (figure 1) close to the "business network" cluster focus specifically on innovation as a network outcome. Next, the four main clusters will be described in more detail. 
Postprint version of article Tourism networks unravelled; a review of the literature on networks in tourism management studies by Egbert van der Zee \& Dominique Vanneste published in Tourism Management

Perspective, 15 (July 2015), pp 46-56

figure 1 Citation network (n 90) including modularity analysis

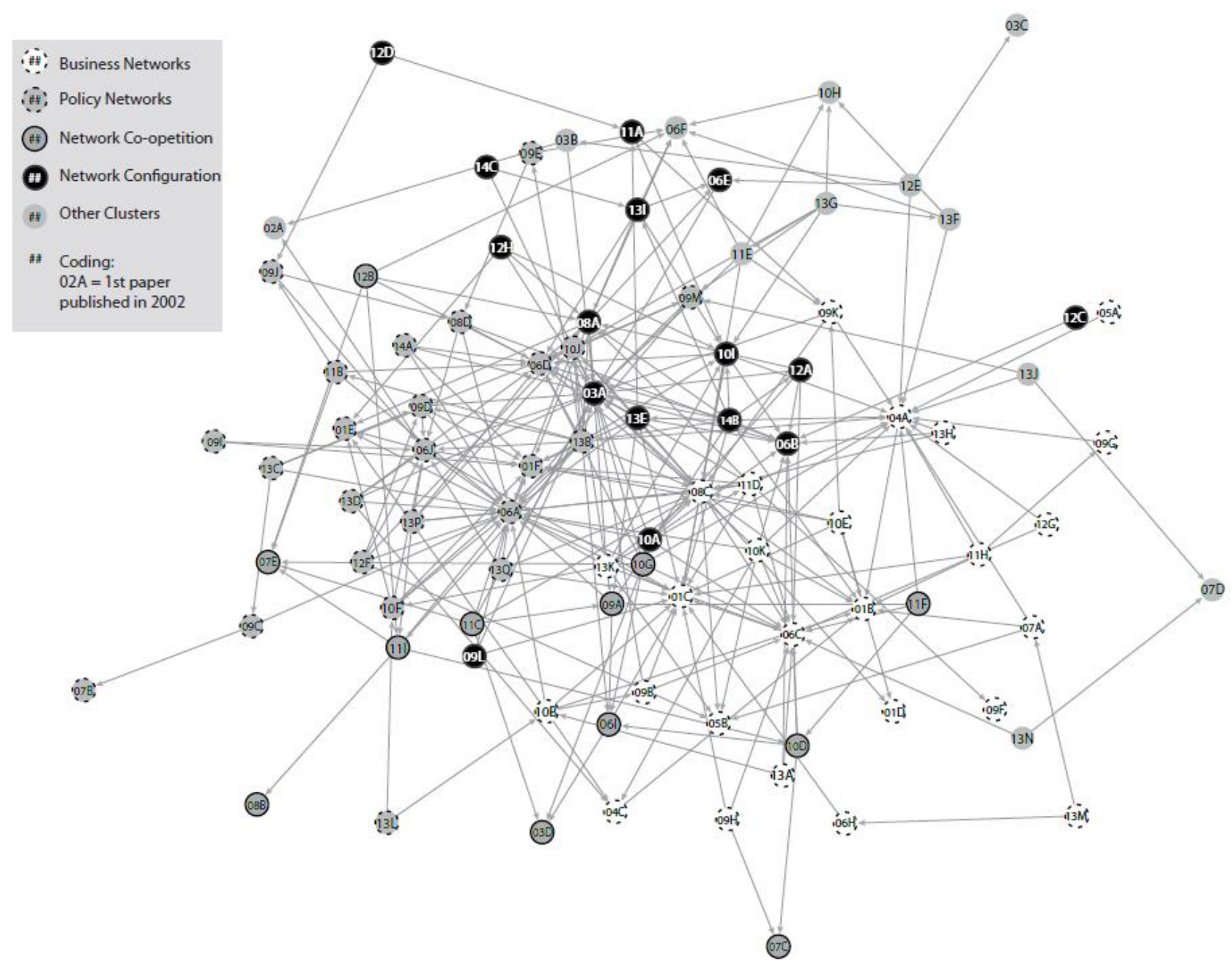

\subsection{The structure of network studies within the tourism domain}

\subsubsection{Policy networks}

Studies in the category "policy networks" focus on the relationships between government, businesses and civil society and how these relationships shape policy making, issue identification, communication, sharing of resources and collective action (Hall, 1999). These studies mainly build on the work by Dredge (2006a; 2006b), who applied network theory for unravelling policymaking and understanding public-private relations in an Australian case. She draws on both, economic geographical (e.g. Porter, 1990) and governance conceptualizations (Tyler \& Dinan, 2001) of networks, but with a goal to understand how "networks can be used as an organizing concept to understand the messiness of local tourism networks' (Dredge, 2006a, p 279). Findings help to understand the dynamic practice of tourism planning and management, which is characterized by imbalanced power relations and complexity (Dredge, 2006b). 
Postprint version of article Tourism networks unravelled; a review of the literature on networks in tourism management studies by Egbert van der Zee \& Dominique Vanneste published in Tourism Management Perspective, 15 (July 2015), pp 46-56

A number of studies indicate that hierarchically, top down organized destinations with a powerful public stakeholder see a low level of network participation by other stakeholders such as community members and tourism entrepreneurs (Pforr, 2006; Bhat \& Milne, 2008; Cooper et al., 2009). Special attention is given to the role of a local public, or public-private tourism organization or destination management organization (DMO) as an important stakeholder in tourism networks. The DMO and other policymaking entities are in subsequent papers discussed as important nodes in a hierarchical network structure where policymaking and implementation were seen as a top-down process with limited influence, inclusion and feedback from tourism businesses or the wider community (Pforr, 2006; Cooper et al., 2009; Beaumont \& Dredge, 2010). Beaumont \& Dredge (2010) argue that a gap exists between network theory and the practical situation in tourism destinations where a short term vision towards economic benefits, a high level of bureaucracy, low levels of trust among entrepreneurs and a lack of knowledge of the tourism industry among policy makers is often present.

Other, more recent, contributions however state that policy networks have the potential to empower stakeholders and provide equal access to resources and to participate in the decision making process (March \& Wilkinson, 2009; Viken \& Aarsaether, 2013; Halkier, 2014; Charlie, King, \& Pearlman, 2014). A process of specialization takes place, placing local communities and sustainability issues in a more central position. Like in the earlier works on policy networks, these contributions try to unravel the factors affecting the level of influence stakeholders have on policymaking. These factors range from very general ones as levels of power (Viken \& Aarsaether, 2013) to very specific factors as entrepreneurial reputation (Strobl \& Peeters, 2013). The novelty in these new contributions is that they move from the conceptualization of the network as a representation of public-private relationships to a more holistic interpretation of the network. The structure and configuration of the network and the way these affect policy outcomes are more often the focus of recent policy network studies (Presenza \& Cipollina, 2010).

In a number of case studies following this network approach, successful network development was found which originated through brokerage by public sector stakeholders (Presenza \& Cipolina, 2010). Either the local DMO or individually operating brokers described as "network champions" were successful in creating a tourism network which caused diversification of the tourist product, more equity among stakeholders and better 
Postprint version of article Tourism networks unravelled; a review of the literature on networks in tourism management studies by Egbert van der Zee \& Dominique Vanneste published in Tourism Management Perspective, 15 (July 2015), pp 46-56

chances for small and medium enterprises to enter the tourism sector (Viken \& Aarsaether, 2013), or in another case study led to the involvement of the wider community into the tourism sector (Iorio \& Corsale, 2014). Successful network collaboration and associated network benefits have been empirically demonstrated for small scaled tourism destinations with a limited number of stakeholders and close economic, cultural and geographical distance between the stakeholders.

\subsubsection{Business networks}

Most of the studies in the tourism business network cluster are of a very explorative nature and offer a broad conceptualization of tourism networks. Compared to the policy network cluster, the field of studies into "business networks" is less coherent. The network graph (figure 1) shows that the business network cluster is less dense and features a large number of sparsely connected nodes and outliers. Two studies can be seen as the base of further work delving into business networks and the associated intra firm collaboration (Tinsley \& Lynch, 2001; Morrison et al., 2004). Studies in the business network are likely to build upon the economic organization of tourism by private stakeholders as proposed by Tremblay (1998). Business network studies depart from a perspective of a horizontal, nonhierarchical self-organizing network of tourism firms consisting of dense local ties and weak global ties which is supported and/or funded by public bodies and organized by local champions or leading managers. This network structure is argued to be beneficial for knowledge sharing, innovation and collective learning, but empirical evidence is lacking.

Perceived benefits for businesses and the development of tourism destinations are featured in the majority of the business network studies. Building upon the work of Porter (1990), Morrison et al. (2004), state that networks are a formalized form of collaboration to reach a common purpose that results in a wide range of quantitative and/or qualitative benefits for network members. Furthermore, they underline that tourism destinations may profit from network collaboration, ranging from an increased sense of community to an extension of the visitor season of the destination. More recent studies into business networks tend to apply a more narrow focus on the perceived benefits of tourism networks: following the work of Halme (2001) innovation, knowledge sharing and collective learning have become the main focus of several tourism network studies (see e.g. Novelli et al., 2006 or Kelliher \& Reinl, 2011). Sørensen (2007, p.31) refers to various authors when stating that local destination networks are essential for destination development because they sustain learning, integrate local know-how, link fragmented capabilities and sustain innovations. 
Postprint version of article Tourism networks unravelled; a review of the literature on networks in tourism management studies by Egbert van der Zee \& Dominique Vanneste published in Tourism Management Perspective, 15 (July 2015), pp 46-56

Network outcomes in general, and concrete tangible benefits for the network members in particular are argued to be important drivers behind network formation and development (Tinsley \& Lynch, 2001; Fuglsang \& Eide, 2013).

Almost no studies empirically prove (tangible) network outcomes. In a number of cases, a restrictive network organization with a dominant public sector stakeholder impeded network outcomes for its members (Copp \& Ivy, 2001), but in more cases it was found that small and medium tourism businesses are not likely to actively participate in tourism networks (Sørensen, 2007; Erkuş-Öztürk, 2009; de Klerk \& Saayman, 2012). A lack of social capital and network skills, time and budget constraints or a dominant position of larger tourism businesses were argued to cause this low participation in business networks. Destinations with less cultural, economic and geographic distance between tourism businesses were seen as the most likely locations where successful network formation could take place (Sørensen, 2007; Deery, O’Mahony, \& Moors, 2012). For the effectivity of network development, public parties were suggested to play a less dominant, more facilitating role. For instance, it was suggested that - as an example of public party involvement - public stakeholders should facilitate training opportunities to gain network skills (Erkuş-Öztürk, 2009; de Klerk \& Saayman, 2012).

While most studies in this cluster focus on factors that stimulate or impede network formation, just a few studies look into the actual network outcomes. Interestingly, these are all case-studies about beach-destinations in different parts of the world (Spain, United Kingdom, South India and Turkey). Sørensen (2007) concludes from a case-study in Malaga (Spain) that network participation might improve information sharing, but that it was not found to foster innovation. Learning and sharing of information were also found as network outcomes by McLeod, Vaughan and Edwards (2010), who did a case-study in Bournemouth (UK). Kokkranikal and Morrison (2011) show in an eco-resort in South India how a privatecommunity network can be established that causes a socially sustainable tourism development with community involvement. Finally, in a case-study performed in Antalya (Turkey), Erkuş-Öztürk \& Eraydin (2010) show how local tourism networks might contribute to a sustainable use of resources which are vital for the tourism destination with the example of collaborative action towards environmental protection by various tourism stakeholders. Bringing tourism businesses closer together, stimulating communications and the creation of a business community have been the most important empirically proven outcomes of tourism networks. 
Postprint version of article Tourism networks unravelled; a review of the literature on networks in tourism management studies by Egbert van der Zee \& Dominique Vanneste published in Tourism Management Perspective, 15 (July 2015), pp 46-56

\subsubsection{Co-opeting networks}

A selection of studies on tourism networks distinguishes itself by focusing on relationships between tourism stakeholders and the nature of their relationships. Following the work of Porter (1990), participating in a tourism network is believed to assist in finding a balance between competition and collaboration which increases both stakeholder and destination performance (Petrou, Pantziou, Dimara, \& Skuras, 2007; Denicolai et al., 2010). This cluster contains papers that combine both business and policy network perspectives and to a certain extent integrates both subfields. While inter firm interactions are an important focus in this cluster, the relationship with public or public-private destination managers is also a central theme. Findings suggest that informal networks, based on social, economic and cultural proximity are most likely to produce positive network outcomes (Zach \& Racherla, 2011). However, the presence of dominant (public) institutions (e.g. DMOs) are found to impede network formation (Petrou et al., 2007). Horizontal network structures are suggested, with competent public sector management, or public-private or private network brokers, organizing the tourism network (Lemmetyinen \& Go, 2009). A successful tourism network consists of tourism businesses that work together in an interdependent balance of coopetition, fueled by trust and reciprocity (Beritelli, 2011).

While this cluster gives an insight into the question when tourism businesses are likely to cooperate, it gives a very limited empirical prove of network outcomes. Hints towards network benefits are given by Wang \& Fesenmaier (2007) who claim network participation leads to organizational learning, social capital creation and the formation of communal business strategies. Lemmetyinen \& Go (2009) take a different position towards the outcomes of network participation and turn the relationship the other way around. They state that when a destination is able to create a level of network collaboration among its tourism stakeholders, further cooperation between tourism firms can be a network outcome. This level of cooperation can lead to the creation and diffusion of joint knowledge (Lemmetyinen \& Go, 2009), increasing individual firm performance and destination performance (Ramayah et al., 2011), the integration of the tourism sector and the offering of an integrated tourism experience for visitors (Zehrer \& Raich, 2010; Denicolai et al., 2010). In other words, increasing levels of cooperation are an important outcome of tourism networks, which are depicted as a fluid, evolving, horizontal web of stakeholder interactions with one or more common goals. 
Postprint version of article Tourism networks unravelled; a review of the literature on networks in tourism management studies by Egbert van der Zee \& Dominique Vanneste published in Tourism Management Perspective, 15 (July 2015), pp 46-56

The positive network outcomes mentioned by the papers in this cluster are a combination of outcomes mentioned in the policy network clusters (access to resources and influence on policy), but are complemented by successful business network collaboration outcomes, such as learning and sharing of knowledge, creating economies of scale through the integration of the tourism destination and the capability to adapt to external influences. However, almost no tangible proof is given by the empirical studies, as most emphasis was given to explaining how and why tourism stakeholders participate in tourism networks. A weakness in this cluster of network studies is that while there is a strong emphasis on stakeholder relations in networks, almost no attention is given to the configuration of the tourism network as a whole, or the different type of network relations that can exist.

\subsubsection{Network configuration}

The second cluster that integrates both policy and business network studies focuses on network structure and topology. This cluster applies (social) network analysis to unravel the structure of tourism networks and applies a technical conceptualization of tourism networks based on links between stakeholders and (quantitative) measures of network performance (Scott et al., 2008a). The position of the network stakeholder is determined by the links he or she has with other stakeholders and the nature of these links. This position is expressed by measures as centrality, degree, closeness and betweenness (Timur \& Getz, 2008; Baggio et al., 2010). These relationships do not occur in a vacuum of dyadic ties, but rather in a network of influences (Pavlovich, 2003). The presence of both strong and weak ties and close and far connections are important in this definition. Network topologies and structures are used to give an insight in (a) the organization structure of destinations, (b) the potential for sharing of information and innovation, (c) access to and management of resources and power relations, (d) flexibility and adaptability and (e) show where improvement of connections between stakeholders might benefit the destination.

Benefits assigned to network collaboration by papers in the "network configuration" cluster resemble previously mentioned network outcomes. Competitive advantage, due to sharing of knowledge and access to information that leads to innovation (Baggio et al., 2010) is one of the frequently mentioned benefits. Management of and access to resources (Romeiro \& Costa, 2010; Schaffer \& Lawley, 2012; Hazra, Fletcher, \& Wilkes, 2014) is another prominent benefit for tourism stakeholders and destinations stressed by these studies. A novel application of network theory on tourism destinations that could lead to competitive 
Postprint version of article Tourism networks unravelled; a review of the literature on networks in tourism management studies by Egbert van der Zee \& Dominique Vanneste published in Tourism Management Perspective, 15 (July 2015), pp 46-56

advantage is also presented. By knowing the network configuration of a destination, a more comprehensive and integrated tourism planning can be achieved (Cooper et al., 2009;

Schaffer \& Lawley, 2012). The density of network ties can indicate the likeliness network stakeholders share information or the level of trust and reciprocity between network members (Schaffer \& Lawley, 2012; Del Chiappa \& Presenza, 2013).

Applying network theory and analysis, a number of studies found network structures which impeded development of the tourism structure due to dominant positions of (public sector) stakeholders (Pavlovich, 2003; Timur \& Getz, 2008; Noguiera \& Pinho, 2014). In other studies on network configuration, sparse and weak network structures were found to negatively influence collaboration and information sharing (Baggio et al., 2010; Baggio, 2011), although the presence of a network connection that bridges structural holes might link local tourism networks to new information and knowledge (Schaffer \& Lawley, 2012). New methodological techniques are applied to uncover stakeholder resilience through network composition (Schaffer \& Lawley, 2012) and measure power relations through stakeholder relationships and network position (Hazra et al., 2014) in more recent papers. Even though these methodological advances have provided valuable insights for destination managers on the applicability of network analysis for tourism planning and destination management, it still does not show how, and to what extent these network topologies lead to tangible network outcomes.

\subsection{Schematic representation of the main results}

In general, benefits of networked collaboration are suggested to entail the creation and diffusion of knowledge and innovation, quality improvement of tourism product offering, a higher quality of service provision, a more efficient production process, an increasing sustainability of the destination and in total a more competitive destination. These assumed benefits of networked collaboration can be found in papers from all four proposed subfields. In theory, the level of success is attributed to the composition and configuration of the tourism network. In practice however, networks are conceptualised differently in the various fields and benefits from networked collaboration for stakeholders and the destination are perceived differently. The same goes for the kind of network outcomes that are empirically proven in the different studies. The four main subfields found in the modularity analysis show internally a lot of consistencies, but some differences between the subfields are notable. Table 1 gives an overview of the different subfields and lists the most found internal consistencies and external differences. 
Postprint version of article Tourism networks unravelled; a review of the literature on networks in tourism management studies by Egbert van der Zee \& Dominique Vanneste published in Tourism Management

Perspective, 15 (July 2015), pp 46-56

table 1:Schematic representation of the four sub clusters

\begin{tabular}{|c|c|c|c|}
\hline & Conceptualisation & Projected network benefits & Empirically proven network benefits and outcomes \\
\hline $\begin{array}{l}\text { Business } \\
\text { networks }\end{array}$ & $\begin{array}{l}\text { Networking is a tool to enhance } \\
\text { firm performance. The firm is the } \\
\text { main study object; the main topic is } \\
\text { the question whether joining a } \\
\text { tourism network could produce } \\
\text { benefits for tourism firms. }\end{array}$ & $\begin{array}{l}\text { Wide range of benefits for firms: } \\
\text { - competitive advantage } \\
\text { - interorganisational learning } \\
\text { - increased sector performance } \\
\text { - innovation } \\
\text { - lowering transaction costs } \\
\text { - added value } \\
\text { - increased social capital and skills }\end{array}$ & $\begin{array}{l}\text { Benefits of tourism networks are seldom proven. Study } \\
\text { findings go into: } \\
\text { - The question how to organise a tourism network } \\
\text { - The role of brokers and public or public/private institutions } \\
\text { in network organisation. } \\
\text { - Variables affecting the likeliness a firm will enter a } \\
\text { networked collaboration }\end{array}$ \\
\hline $\begin{array}{l}\text { Policy } \\
\text { networks }\end{array}$ & $\begin{array}{l}\text { Networks provide access to } \\
\text { resources and can be an alternative } \\
\text { to traditional destination } \\
\text { government. Studies address public- } \\
\text { private relationships, power } \\
\text { relations within the network and } \\
\text { network hierarchies. }\end{array}$ & $\begin{array}{l}\text { Main focus on benefits for the destination: } \\
\text { - (equal) access to resources } \\
\text { - sustainable development } \\
\text { - sustainable resource management } \\
\text { - conservation } \\
\text { - democratic collaboration } \\
\text { - reciprocity among stakeholders } \\
\text { - competitive advantage } \\
\text { - social capital enhancement }\end{array}$ & $\begin{array}{l}\text { Applying a network perspective helps to understand the } \\
\text { complex dynamic of tourism decision making and destination } \\
\text { planning by uncovering power structures. } \\
\text { - Top-down organised destinations were argued to have a } \\
\text { restrictive governance structure which impedes reaping the } \\
\text { projected network benefits. } \\
\text { - Inclusive, horizontal networks were found to assist resources } \\
\text { management, community involvement and conservation }\end{array}$ \\
\hline $\begin{array}{l}\text { Co-opeting } \\
\text { networks }\end{array}$ & $\begin{array}{l}\text { Networks are means to reach a } \\
\text { balance between competition and } \\
\text { collaboration which enhances } \\
\text { competitiveness. Managing a } \\
\text { destination from a network } \\
\text { perspective could foster co-opetive } \\
\text { relationships when not impeded by } \\
\text { hierarchical relationships and power } \\
\text { imbalances. }\end{array}$ & $\begin{array}{l}\text { Benefits enhance destination performance: } \\
\text { - value creation } \\
\text { - increasing social capital among stakeholders } \\
\text { - improving quality and experience for visitors } \\
\text { - co-creation of tourism experiences } \\
\text { - creating economies of scale } \\
\text { - building a successful destination brand } \\
\text { - inclusive and integrated tourism destination }\end{array}$ & $\begin{array}{l}\text { Network benefits have not been empirically proven, but it is } \\
\text { indicated that the destination management structure determines } \\
\text { the level of network benefits. } \\
\text { - Projected network benefits are impeded by hierarchical } \\
\text { destination management structures. } \\
\text { - Commitment and communication are seen as driving forces } \\
\text { behind collaboration between tourism stakeholders } \\
\text { - Network brokers or champions can successfully enhance the } \\
\text { organisation of tourism networks }\end{array}$ \\
\hline $\begin{array}{l}\text { Network } \\
\text { configuration }\end{array}$ & $\begin{array}{l}\text { Networks are a set of interrelations } \\
\text { between tourism stakeholders. The } \\
\text { configuration, structure and } \\
\text { topology of the network, the } \\
\text { presence of links between nodes and } \\
\text { the nature of the links determine the } \\
\text { performance of a tourism } \\
\text { destination. }\end{array}$ & $\begin{array}{l}\text { Benefits for network participants originate } \\
\text { from the flow of information, collaboration } \\
\text { and access to resources: } \\
\text { - innovation } \\
\text { - competitive advantage } \\
\text { - resilience, the ability to adjust to } \\
\text { uncertainty and cope with complex } \\
\text { situations }\end{array}$ & $\begin{array}{l}\text { The configuration of the network was found to influence } \\
\text { network benefits in small-scale destinations with a flat } \\
\text { organisation structure: } \\
\text { - inclusive tourism planning } \\
\text { - a culture of reciprocity among stakeholders } \\
\text { - resilience towards external threats } \\
\text { - creation and diffusion of information and knowledge } \\
\text { - better performance of the tourism destination. }\end{array}$ \\
\hline
\end{tabular}

\section{Discussion}

Over the past two decades, a growing number of studies has been published which focus on the role of networks in tourism. Interestingly, the roots are still visible of the papers that introduced the network concept into the tourism literature at the end of the 1990's (Jamal \& Getz, 1995; Tremblay, 1998; Hall, 1999). The main body of the reviewed literature consists of two main types of network studies: policy networks (building upon Hall, 1999 and Jamal \& Getz, 1995) and business networks (building upon Tremblay, 1998). Based on the modularity analysis, these seem to be distinct fields of study, which both have their own scientific community and hardly have any mutual impact. This has to be regretted because both fields encounter the same type of problems. Network outcome claims are manifold, but except for a limited amount of case-studies that draw upon stakeholder evaluation of tourism networks (e.g. Erkuş-Öztürk \& Eraydin, 2010; Viken \& Aarsaether, 2013) few tangible, quantitative benefits have been found which might persuade tourism entrepreneurs to invest time and money in local tourism networks. 
Postprint version of article Tourism networks unravelled; a review of the literature on networks in tourism management studies by Egbert van der Zee \& Dominique Vanneste published in Tourism Management Perspective, 15 (July 2015), pp 46-56

The citation analysis shows that over the last few years two additional clusters of papers have emerged that try to bridge the gap between these two fields. One field is labelled "network co-opetition" due to the dominant proposition that destinations benefit from a balanced web of relations between stakeholders which fosters collaboration but also permits competition between the network nodes. Together, this should lead to competitive advantage for the participants and the destination. Unfortunately, these projected benefits of balanced network collaboration are not yet empirically proven by the papers in this field. Empirical results focus on the nature of the collaboration between stakeholders and the role public or public-private network facilitators play in network development. In most studies, reasons are given why networks are impeded by either a dominant public sector stakeholder or by a lack of social capital and network skills among entrepreneurs. The most important finding from this field of studies shows that network relationships are strengthened by an ongoing communication dialogue between the network stakeholders, which is more successful when cultural, economic and geographic distance is low and clear common goals can be distinguished.

While the "network co-opetition" subfield studies stakeholder relationships in-depth, a more holistic view on the tourism network is lacking. The last major subfield discussed here does take this holistic view into account. Departing from a mathematical conceptualisation of the network as a collection of network nodes and ties with a distinguishable structure, this field of studies for the first time departs from the network as an entity and not a mere concept. Pavlovich (2003) was the first author exploring this perspective in her longitudinal case study of tourism development surrounding the Waitomo Caves in New Zealand, but the subfield matured by the contributions by Scott et al. (2008a; 2008b) and Baggio et al. (2010) who approached the network from a quantitative, mathematical perspective and developed a methodology to study the tourism network as an entity. These papers relied strongly on previous research on tourism networks and combined it with findings from other fields where network theory has been applied more extensively. This can be regarded as a step forward, because papers which succeed in bridging the gap between scientific communities tend to facilitate knowledge diffusion between these, after all, closely related subfields. The contributions by, among others, Scott et al. (2008a; 2008b) and Baggio et al. (2010) mainly helped in developing the epistemology and methodology of tourism network research. The network itself moved to a central position in this branch of tourism research. 
Postprint version of article Tourism networks unravelled; a review of the literature on networks in tourism management studies by Egbert van der Zee \& Dominique Vanneste published in Tourism Management Perspective, 15 (July 2015), pp 46-56

The more recent contributions in this subfield provide empirically proven network outcomes that could be of use for tourism researchers and destination managers. For example, Luthe et al. (2012) show how a network structure influences destination resilience to climate change in destinations in the Austrian Alps. Being able to adapt to external influences is an important beneficial outcome ascribed to networks by the early adaptors of network theory in tourism. It thus seems that this subfield, which draws upon contributions from the other subfields, develops into a field which is able to not only create an epistemology that departs from the network as an entity, but also is becoming able to provide tangible and useful network outcomes that are able to assist destination managers and tourism planners.

To conclude, the field would benefit from more knowledge diffusion between the various subfields. This paper has demonstrated that many researchers remain within their own, relatively narrow research network, and profit too little from knowledge produced in closely related fields. The recent turn in network studies in tourism seems to be able to break away from this lock-in formed around either policy network clusters or business network clusters. The second conclusion is that, while many studies show interesting and promising findings, the field would make more progress, if researchers would reflect more systematically on the relationship between network goals and projected outcomes, and on the most suitable methodology to test the effects of the desired network development in a comprehensive way. Too often, papers depart from a seemingly given and fairly general set of assumed network outcomes (innovation, learning, quality improvement, sustainable economic development) and choose a methodology which is not fit to provide firm evidence whether or not these goals are reached. In combination, these two conclusions have important practice implications. Combining insights from policy network and business network perspectives, the contributions from the field of "network co-opetition" indicate that communicating common network goals are central to network success (Lemmetyinen \& Go, 2009).

When the goals and interests of different stakeholders do not coincide, are impossible to align or are regarded as inconceivable, forming and maintaining a network is impossible. Two steps should be taken to align the goals and interests of stakeholders. First, there should be a clear and open communication about the goals of the various actors as well as of the network as a whole. Skewed power relations or badly configured networks impede this communication, and thus network development, and on the long run impede network 
Postprint version of article Tourism networks unravelled; a review of the literature on networks in tourism management studies by Egbert van der Zee \& Dominique Vanneste published in Tourism Management Perspective, 15 (July 2015), pp 46-56

benefits. Second, examples of best practices should be provided which visualize and explain the benefits of working together in a network. These insights, originating from in-depth and subfield overarching research provide useful recommendations for tourism management, like the finding that hierarchical network structures with a dominant stakeholder (often a DMO) are impeding network formation and outcomes.

Even though some recent papers empirically investigate network outcomes, the claim by Morrison et al. (2004) that the perceived benefits of engaging in a network are of a highly qualitative and fuzzy nature still holds after a decade of tourism network research. Papers evaluating network performance and indicating tangible network outcomes are scarce. To further develop the field of network studies, papers that aim to empirically proof network outcomes are necessary. Being more precise (and maybe more modest) in articulating tangible goals is an important first step. An innovative additional way to fulfil this quest might be to include the tourist in network research. While tourists are the users and thus the main evaluators of network performance, they are seldom included in the tourism network studies so far (but see Shih, 2006 for a notable exception). As the provision of a high quality experience and the creation of value for consumers are seen as important outcomes of successful network collaboration, empirical evidence on the relation between network collaboration and tourist experience is highly desirable. Including evaluative measures in tourism network studies could connect this field with the wider debate on co-creation of the tourist experience, and by doing this provide new and valuable insights for both fields of research. 
Postprint version of article Tourism networks unravelled; a review of the literature on networks in tourism management studies by Egbert van der Zee \& Dominique Vanneste published in Tourism Management Perspective, 15 (July 2015), pp 46-56

\section{References}

Adiyia, B., Stoffelen, A., Jennes, B., Vanneste, D., \& Ahebwa, W.M. (2015). Analysing governance in tourism value chains to reshape the tourist bubble in developing countries, the case of cultural tourism in Uganda. Journal of Ecotourism, forthcoming. DOI: $10.1080 / 14724049.2015 .1027211$

Albrecht, J.N. (2013). Networking for sustainable tourism - towards a research agenda. Journal of Sustainable Tourism, 21(5), 639-657. DOI: 10.1080/09669582.2012.721788

Baggio, R. (2011). Collaboration and cooperation in a tourism destination: A network science approach. Current Issues in Tourism, 14(2), 183-189. DOI: 10.1080/13683500.2010.531118

Baggio, R., Scott, N., \& Cooper, C. (2010). Network science; a review focused on tourism. Annals of Tourism Research, 37(3), 802-827. DOI: 10.1016/j.annals.2010.02.008

Beaumont, N., \& Dredge, D. (2010). Local tourism governance: a comparison of three network approaches. Journal of Sustainable Tourism, 18(1), 7-28. DOI: $10.1080 / 09669580903215139$

Benckendorff, P., \& Zehrer, A. (2013). A network analysis of tourism research. Annals of Tourism Research, 43, 121-149. DOI: 10.1016/j.annals.2013.04.005

Beritelli, P. (2011). Cooperation among prominent actors in a tourism destination. Annals of Tourism Research, 38(2), 607-629. DOI: 10.1016/j.annals.2010.11.015

Bhat, S.S., \& Milne, S. (2008). Network effects on cooperation in destination website development. Tourism Management, 29(6), 1131-1140. DOI: 10.1016/j.tourman.2008.02.010

Borgatti, S.P., Everett, M.G., \& Freeman, L.C. (2002). Ucinet for Windows: Software for Social Network Analysis. Harvard: Analytic Technologies. 
Postprint version of article Tourism networks unravelled; a review of the literature on networks in tourism management studies by Egbert van der Zee \& Dominique Vanneste published in Tourism Management Perspective, 15 (July 2015), pp 46-56

Boschma, R.A., \& Frenken, K. (2006). Why is economic geography not an evolutionary science? Towards an evolutionary economic geography. Journal of Economic Geography 6(3), 273-302. DOI: 10.1093/jeg/lbi022

Bramwell, B., \& Lane, B. (2000). Tourism Collaboration and Partnerships: Politics, Practice and Sustainability. Clevedon: Channel View Publications.

Buhalis, D. (2000). Marketing the competitive destination of the future. Tourism Management, 21(1), 97-116. DOI: 10.1016/S0261-5177(99)00095-3

Cawley, M., Marsat, J-B., \& Gillmor, D.A. (2007). promoting integrated rural tourism: comparative perspectives on institutional networking in France and Ireland. Tourism Geographies: An International Journal of Tourism Space, Place and Environment, 9(4), 405420. DOI: $10.1080 / 14616680701647626$

Charlie, C., King, B., \& Pearlman, M. (2013). The application of environmental governance networks in small island destinations: Evidence from Indonesia and the Coral Triangle. Tourism Planning \& Development, 10(1), 17-31. DOI: 10.1080/21568316.2012.730056

Cooper, C., Scott, N., \& Baggio, R. (2009). Network position and perceptions of destination stakeholder importance. Anatolia: An International Journal of Tourism and Hospitality Research, 20(1), 33-45. DOI: 10.1080/13032917.2009.10518893

Copp, C.B., \& Ivy, R.L. (2001). Networking trends of small tourism businesses in postsocialist Slovakia. Journal of Small Business Management, 39(4), 345-353. DOI: DOI: $10.1111 / 0447-2778.00031$

Deery, M., O’Mahony, G.B., \& Moors, R. (2013). Employing a lifecycle typology to generate a unified and strategic approach to regional wine tourism development. Tourism Planning \& Development, 9(3), 291-307. DOI: 10.1080/21568316.2012.672453

de Klerk, S., \& Saayman, M. (2012). Networking as key factor in Artpreneurial success. European Business Review, 24(5), 382 - 399. DOI: 10.1108/09555341211254490 
Postprint version of article Tourism networks unravelled; a review of the literature on networks in tourism management studies by Egbert van der Zee \& Dominique Vanneste published in Tourism Management Perspective, 15 (July 2015), pp 46-56

Del Chiappa, G. \& Presenza, A. (2013). The use of network analysis to assess relationships among stakeholders within a tourism destination: an empirical investigation on Costa Smeralda-Gallura, Italy. Tourism Analysis, 18(1), 1-13. DOI: $10.3727 / 108354213 X 13613720283520$

Denicolai, S., Cioccarelli, G., \& Zucchella, A. (2010). Resource-based local development and networked core-competencies for tourism excellence. Tourism Management, 31(2), 260-266. DOI: 10.1016/j.tourman.2009.03.002

Dredge, D. (2006a). Policy networks and the local organisation of tourism. Tourism Management, 27(2), 269-280. DOI: 10.1016/j.tourman.2004.10.003

Dredge, D. (2006b). Networks, conflict and collaborative communities. Journal of Sustainable Tourism, 14(6), 562-581. DOI: 10.2167/jost567.0

Dwyer, L., Edwards, D., Mistilis, N., Roman, C. \& Scott, N. (2009). Destination and enterprise management for a tourism future. Tourism Management, 30(1), 63-74. DOI: 10.1016/j.tourman.2008.04.002

Erkuş-Öztürk, H. (2009). The role of clusters types and firm sizes in designing level of network relations: The experience from the Antalya tourism region. Tourism Management, 30(4), 589-597. DOI: 10.1016/j.tourman.2008.10.008

Erkuş-Öztürk, H., \& Eraydin, A. (2010). Environmental governance for sustainable tourism development: Collaborative networks and organisation building in the Antalya tourism region. Tourism Management, 31(1), 113-124. DOI: 10.1016/j.tourman.2009.01.002

Fuglsang, L., \& Eide, D. (2013). The experience turn as 'bandwagon': Understanding network formation and innovation as practice. European Urban and Regional Studies, 20(4), 417-434. DOI: 10.1177/0969776412448090 
Postprint version of article Tourism networks unravelled; a review of the literature on networks in tourism management studies by Egbert van der Zee \& Dominique Vanneste published in Tourism Management Perspective, 15 (July 2015), pp 46-56

Granovetter, M.S. (1973). The strength of weak ties. American journal of sociology, 78(6), $1360-1380$.

Gretzel, U., \& Fesenmaier, D.R. (2003). Implementing a knowledge-based tourism marketing information system: the Illinois tourism network. Information Technology \& Tourism, 6(4), 245-255. DOI: $10.3727 / 1098305032781175$

Gunn, C.A. (1977). Industry pragmatism vs tourism planning. Leisure Sciences, 1(1), 85-94. DOI: $10.1080 / 01490407709512872$

Halkier, H. (2014). Innovation and destination governance in Denmark: Tourism, policy networks and spatial development. European Planning Studies, 22(8), 1659-1670. DOI: $10.1080 / 09654313.2013 .784609$

Hall, C.M. (1999). Rethinking collaboration and partnership: A public policy perspective. Journal of Sustainable Tourism, 7(3), 274-289. DOI:10.1080/09669589908667340

Hall, C.M. (2005). Tourism: Rethinking the Social Science of Mobility. Harlow: PrenticeHall.

Hall, C.M., \& Page, S.J. (2009). Progress in Tourism Management: From the geography of tourism to geographies of tourism - A review. Tourism Management, 30(1), 3-16. DOI: 10.1016/j.tourman.2008.05.014

Halme, M. (2001). Learning for sustainable development in tourism networks. Business Strategy and the Environment, 10(2), 100-114. DOI: 10.1002/bse.278

Haugland, S.A., Ness, H., Grønseth, B-O., \& Aarstad, J. (2011). Development of tourism destinations; an integrated multilevel perspective. Annals of Tourism Research, 38(1), 268290. DOI: $10.1016 /$ j.annals.2010.08.008 
Postprint version of article Tourism networks unravelled; a review of the literature on networks in tourism management studies by Egbert van der Zee \& Dominique Vanneste published in Tourism Management Perspective, 15 (July 2015), pp 46-56

Hazra, S., Fletcher, J., \& Wilkes, K. (2014). An evaluation of power relationships among stakeholders in the tourism industry networks of Agra, India. Current Issues in Tourism, 2014, 1-17. DOI: 10.1080/13683500.2014.887662

Iorio, M., \& Corsale, A. (2014). Community-based tourism and networking: Viscri, Romania. Journal of Sustainable Tourism, 22(2), 234-255. DOI: 10.1080/09669582.2013.802327

Jamal, T.B., \& Getz, D. (1995). Collaboration theory and community tourism planning. Annals of Tourism Research, 22(1), 186-204. DOI: 10.1016/0160-7383(94)00067-3

Kelliher, F., \& Reinl, L. (2011). From facilitated to independent tourism learning networks: connecting the dots. Tourism Planning \& Development, 8(2), 185-197. DOI: $10.1080 / 21568316.2011 .573919$

Knoke, D. (1990). Political networks: the structural perspective. Cambridge: Cambridge University Press.

Kokkranikal, J., \& Morrison, A. (2011). Community networks and sustainable livelihoods in tourism: The Role of Entrepreneurial Innovation. Tourism Planning \& Development, 8(2), 137-156. DOI: 10.1080/21568316.2011.573914

Lemmetyinen, A. (2009). The coordination of cooperation in strategic business networks-the cruise Baltic case. Scandinavian Journal of Hospitality and Tourism, 9(4), 366-386. DOI: $10.1080 / 15022250902978702$

Lemmetyinen, A., \& Go, F.M. (2009). The key capabilities required for managing tourism business networks. Tourism Management, 30(1), 31-40. DOI: 10.1016/j.tourman.2008.04.005

Luthe, T., Wyss, R., \& Schuckert, M. (2012). Network governance and regional resilience to climate change: empirical evidence from mountain tourism communities in the Swiss Gotthard region. Regional Environmental Change, 12(4), 839-854. DOI: 10.1007/s10113012-0294-5 
Postprint version of article Tourism networks unravelled; a review of the literature on networks in tourism management studies by Egbert van der Zee \& Dominique Vanneste published in Tourism Management Perspective, 15 (July 2015), pp 46-56

March, R., \& Wilkinson, I. (2009). Conceptual tools for evaluating tourism partnerships. Tourism Management, 30(3), 455-462. DOI: 10.1016/j.tourman.2008.09.001

McCabe, S., Sharples, M., \& Foster, C. (2012). Stakeholder engagement in the design of scenarios of technology-enhanced tourism services. Tourism Management Perspectives, 4, 36-44. DOI: 10.1016/j.tmp.2012.04.007

McLeod, M.T., Vaughan, D.R., \& Edwards, J. (2010). Knowledge networks in the tourism sector of the Bournemouth, Poole and Christchurch conurbation: Preliminary analysis. The Service Industries Journal, 30(10), 1651-1667. DOI: 10.1080/02642060903580664

Melián-González, A., \& García-Falcón, J.M. (2003). Competitive potential of tourism in destinations. Annals of Tourism Research, 30(3), 720-740. DOI: 10.1016/S01607383(03)00047-1

Miller, G.A., \& Ritchie, B.W. (2003). A farming crisis or a tourism disaster? An analysis of the foot and mouth disease in the UK. Current Issues in Tourism, 6(2), 150-171. DOI: $10.1080 / 13683500308667949$

Morrison, A., Lynch, P. \& Johns, N. (2004). International tourism networks. International Journal of Contemporary Hospitality Management, 16(3), 197-202. DOI: 10.1108/IJLPS-052013-0012

Noguiera, S., \& Pinho, J.C. (2014). Stakeholder network integrated analysis: the specific case of rural tourism in the Portugese Peneda-Geres National Park. International Journal of Tourism Research, 2014, 1-12. DOI: 10.1002/jtr.1989

Novelli, M., Schmitz, B., \& Spencer, T. (2006). Networks, clusters and innovation in tourism: A UK experience. Tourism Management, 27(6), 1141-1152. DOI:

10.1016/j.tourman.2005.11.011 
Postprint version of article Tourism networks unravelled; a review of the literature on networks in tourism management studies by Egbert van der Zee \& Dominique Vanneste published in Tourism Management Perspective, 15 (July 2015), pp 46-56

Pavlovich, K. (2003). The evolution and transformation of a tourism destination network: the Waitomo Caves, New Zealand. Tourism Management, 24(2), 203-216. DOI: 10.1016/S02615177(02)00056-0

Petrou, A., Pantziou, E.F., Dimara, E., \& Skuras, D. (2007). Resources and activities complementarities: The role of business networks in the provision of integrated rural tourism. Tourism Geographies: An International Journal of Tourism Space, Place and Environment, 9(4), 421-440. DOI: 10.1080/14616680701647634

Pforr, P. (2006). Tourism policy in the making: An Australian network study. Annals of Tourism Research, 33(1), 87-108. DOI: 10.1016/j.annals.2005.04.004

Porter, M.E. (1990). The competitive advantage of nations. London: Macmillan.

Presenza, A., \& Cipollina, M. (2010). Analysing tourism stakeholders networks. Tourism Review, 65(4), 17 - 30. DOI: 10.1108/16605371011093845

Provan, K.G., \& Kenis, P. (2008). Modes of network governance: structure, management, and effectiveness. Journal of Public Administration Research and Theory, 18(2), 229-252. DOI: $10.1093 /$ jopart/mum015.

R Core Team (2013). R: A language and environment for statistical computing. Vienna: $\mathrm{R}$ Foundation for Statistical Computing

Ramayah, T., Lee, J.W.C., \& In, J.B.C. (2011). Network collaboration and performance in the tourism sector. Service Business, 5(4), 411-428. DOI: 10.1007/s11628-011-0120-z

Romeiro, P., \& Costa, C. (2010). The potential of management networks in the innovation and competitiveness of rural tourism: a case study on the Valle del Jerte (Spain). Current Issues in Tourism, 13(1), 75-91. DOI: 10.1080/13683500902730452

Saxena, G. (2005). Relationships, networks and the learning regions: case evidence from the Peak District National Park. Tourism Management, 26(2), 277-289. DOI:

10.1016/j.tourman.2003.11.013 
Postprint version of article Tourism networks unravelled; a review of the literature on networks in tourism management studies by Egbert van der Zee \& Dominique Vanneste published in Tourism Management Perspective, 15 (July 2015), pp 46-56

Schaffer, V., \& Lawley, M. (2012). An analysis of the networks evolving from an artificial reef development. Current Issues in Tourism, 15(5), 497-503. DOI:

$10.1080 / 13683500.2011 .638704$

Scott, N., Baggio, R., \& Cooper, C. (2008a). Network Analysis and Tourism: From Theory to Practice. Clevedon: Channel View Publications.

Scott, N., Cooper, C., \& R. Baggio (2008b). Destination networks; four Australian case studies. Annals of Tourism Research, 35(1), 169-188. DOI: 10.1016/j.annals.2007.07.004

Shih, H. (2006). Network characteristics of drive tourism destinations: An application of network analysis in tourism. Tourism Management, 27(5), 1029-1039. DOI:

10.1016/j.tourman.2005.08.002

Sørensen, F. (2007). The geographies of social networks and innovation in tourism. Tourism Geographies: An International Journal of Tourism Space, Place and Environment, 9(1), 2248. DOI:10.1080/14616680601092857

Strobl, A., \& Peeters, M. (2013). Entrepreneurial reputation in destination networks. Annals of Tourism Research, 40(1), 59-82. DOI: 10.1016/j.annals.2012.08.005

Sundbo, J., Orfila-Sintes, F., \& Sørensen, F. (2007). The innovative behaviour of tourism firms - Comparative studies of Denmark and Spain. Research Policy, 36(1), 88-106. DOI: 10.1016/j.respol.2006.08.004

Timur, S., \& Getz, D. (2008). A network perspective on managing stakeholders for sustainable urban tourism. International Journal of Contemporary Hospitality Management, 20(4), 445-461. DOI: http://dx.doi.org/10.1108/09596110810873543

Tinsley, R., \& Lynch, P. (2001). Small tourism business networks and destination development. International Journal of Hospitality Management, 20(4), 367-378. DOI: $10.1016 / \mathrm{S} 0278-4319(01) 00024-\mathrm{X}$ 
Postprint version of article Tourism networks unravelled; a review of the literature on networks in tourism management studies by Egbert van der Zee \& Dominique Vanneste published in Tourism Management Perspective, 15 (July 2015), pp 46-56

Tremblay, P. (1998). The economic organization of tourism. Annals of Tourism Research, 25(4), 837-859. DOI: 10.1016/S0160-7383(98)00028-0

Tyler, D., \& Dinan, C. (2001). The role of interested groups in England's emerging tourism network. Current Issues in Tourism, 4(2-4), 210-252. DOI:10.1080/13683500108667888

Uzzi, B. (1997). Social structure and competition in interfirm networks: The paradox of embeddedness. Administrative Science Quarterly, 42(1), 35-67. DOI: 10.2307/2393808

Van der Zee, E., \& Go, F.M. (2013). Analysing beyond the environmental bubble dichotomy: How the 2010 World Cup case helped to bridge the host-guest gap. Journal of Sport \& Tourism, 18(3), 161-183. DOI: 10.1080/14775085.2014.888674

Vanneste, D., \& Ryckaert, L. (2011). Networking and governance as success factors for rural tourism? The perception of tourism entrepreneurs in the Vlaamse Ardennen. Bulletin de la Société Géographique de Liège, 57, 53-71.

Vargo, S.L., \& Lusch, R.F. (2004). Evolving to a new dominant logic for marketing. Journal of Marketing, 68(1), 1-17. DOI: 10.1509/jmkg.68.1.1.24036

Viken, A., \& Aarsaether, N. (2013). Transforming an iconic attraction into a diversified destination: The case of North Cape tourism. Scandinavian Journal of Hospitality and Tourism, 13(1), 38-54. DOI: 10.1080/15022250.2013.771994

Wang, Y., \& Fesenmaier, D.R. (2007). Collaborative destination marketing: a case study of Elk Hart County, Indiana. Tourism Management, 28(3), 863-875. DOI:

10.1016/j.tourman.2006.02.007

Wäsche, H., Dickson, G., \& Woll, A. (2013). Quality in regional sports tourism: a network approach to strategic quality management. Journal of Sport \& Tourism, 18(2), 81-97. DOI: $10.1080 / 14775085.2013 .826593$ 
Postprint version of article Tourism networks unravelled; a review of the literature on networks in tourism management studies by Egbert van der Zee \& Dominique Vanneste published in Tourism Management

Perspective, 15 (July 2015), pp 46-56

Wray, M. (2009). Policy communities, networks and issue cycles in tourism destination systems. Journal of Sustainable Tourism, 17(6), 673-690. DOI:

$10.1080 / 09669580903071979$

Zach, F., \& Racherla, P. (2011). Assessing the value of collaborations in tourism networks: A case study of Elkhart County, Indiana. Journal of Travel \& Tourism Marketing, 28(1), $97-$ 110. DOI: $10.1080 / 10548408.2011 .535446$

Zehrer, A., \& Raich, F. (2010). Applying a lifecycle perspective to explain tourism network development. The Service Industries Journal, 30(10), 1683-1705. DOI:

$10.1080 / 02642060903580698$ 